\title{
A Report of Chigger Mites on the Striped Field Mouse, Apodemus agrarius, in Southwest China
}

\author{
Yan-Ling Chen ${ }^{1}$, Xian-Guo Guo,* ${ }^{1}$, Tian-Guang Ren², Lei Zhang1, Rong Fan', Cheng-Fu Zhao', Zhi-Wei Zhang', \\ Ke-Yu Mao', Xiao-Bin Huang', Ti-Jun Qian' \\ 1'Institute of Pathogens and Vectors, Yunnan Provincial Key Laboratory for Zoonosis Control and Prevention, Dali University, Dali, Yunnan, 671000, \\ China; ${ }^{2}$ Nursing College of Dali University, Dali, Yunnan, 671000 , China
}

\begin{abstract}
Based on the field investigations in 91 investigation sites (counties) in southwest China between 2001 and 2019, the present paper reported the chigger mites on $A$. agrarius mice in southwest China for the first time by using a series of statistical methods. From 715 striped field mice captured in 28 of 91 investigated sites, only 255 chiggers were collected, and they were identified as 14 species, 6 genera in 3 subfamilies under 2 families. Of $715 A$. agrarius mice, only 24 of them were infested with chigger mites with low overall prevalence $\left(P_{M}=3.4 \%\right)$, overall mean abundance $\left(M_{A}=0.36\right.$ mites/host) and overall mean intensity ( $M_{l}=10.63$ mites/host). The species diversity and infestation of chiggers on $A$. agrarius were much lower than those previously reported on some other rodents in southwest China. On a certain species of rodent, $A$. agrarius mouse in southwest China seems to have a very low susceptibility to chigger infestations than in other geographical regions. Of 14 chigger species, there were 3 dominant species, Leptotrombidium sialkotense, $L$. rupestre and Schoengastiella novoconfuciana, which were of aggregated distribution among different individuals of $A$. agrarius hosts. $L$. sialkotense, one of 6 main vectors of scrub typhus in China, was the first dominant on $A$. agrarius. The species similarity of chigger mites on male and female hosts was low with $C_{s s}=0.25$, and this reflects the sex-bias of different genders of $A$. agrarius mice in harboring different chigger species.
\end{abstract}

Key words: Apodemus agrarius, Acari, chigger mite, ectoparasite, rodent, southwest China

\section{INTRODUCTION}

Chigger mites (trombiclid mites) are a group of tiny arthropods with a complex life cycle including 7 stages, the egg (ovum), deutovum (prelarva), larva, nymphochrysalis, nymph, imgaochrysalis and adult (the male and female). In the life cycle of chigger mites, only the larvae (often called "chiggers") are the ectoparasites of some other animals, and rodents (rats, mice and voles, etc.) are the most important hosts of the larvae [1-3]. Chigger mites are the exclusive vector of scrub typhus (tsutsugamushi diseases) caused by the causative agent Orentia tsutsugamushi (Ot). Scrub typhus is prevalent in the Asia-Pacific region including China with about 1,000,000 cases appearing each year $[1,2,4]$. Besides transmitting scrub typhus, chiggers are also associated with some other zoonotic diseases (zoono-

- Received 24 September 2021, revised 17 November 2021, accepted 18 November 2021.

*Corresponding author (xianguoguo@yahoo.com)

(C) 2021, Korean Society for Parasitology and Tropical Medicine

This is an Open Access article distributed under the terms of the Creative Commons Attribution Non-Commercial License (https://creativecommons.org/licenses/by-nc/4.0) which permits unrestricted non-commercial use, distribution, and reproduction in any

medium, provided the original work is properly cited. ses) like as hemorrhagic fever with renal syndrome, HFRS $[5,6]$. Scrub typhus and HFRS are prevalent in southwest China $[3,7]$.

Rodents and some other small mammals (e.g., insectivores and tree shrews) often harbor lots of chiggers on their body surface $[3,5]$. As a common rodent species in crop fields and some other farmlands, gardens and nearby habitats, the striped field mouse (Apodemus agrarius Pallas, 1771) is widely distributed in central and western Europe, Russia, Mongolia, China, Myanmar, Korea and Japan [8]. Besides destroying agricultural plants and crops as a powerful pest in the distributed regions[8], the striped field mouse (A. agrarius) is also an important reservoir host of some zoonoses such as leptospirosis, Lyme disease, plague, scrub typhus, severe fever with thrombocytopenia syndrome (SFTS) and HFRS, etc. [9-11].

Previously some local investigations once reported the species composition and infestation of chigger mites on A. agrarius mouse in some parts of northeast China and Shandong Province in northern China $[12,13]$. In southwest China, however, there has been no literature reporting chigger mites on $A$. agrarius. From 2001 to 2019, our research group made a series 
of field investigations in 5 provincial regions of southwest China, Yunnan, Guizhou, Chongqing, Sichuan and the east part of Tibet (Xizang Autonomous Region). Based on the original data from the previous field investigations, the present paper reported the chigger mites on the striped field mouse (A. agrarius) in southwest China for the first time.

\section{MATERIALS AND METHODS}

\section{Field investigation and collection of chigger mites}

The original data came from the field investigations in 91 investigation sites (counties) of 5 provincial regions (Yunnan, Guizhou, Chongqing, Sichuan and Tibet) in southwest China between 2001 and 2019 (see Table 1 and Fig. 1 in "Results"). Considering the very wide geographical scope of southwest
China with different latitudes and altitudes, complex topography and a variety of climate types, the field investigations were mainly conducted in relatively warm and dry seasons without much flood (March to May and August to October). A few investigations were made in June and July in some high plateaus with high altitudes and low temperature. Striped field mice, together with some other rodents and small mammals (animal hosts), were captured with mousetraps (Guixi Mousetrap Apparatus Factory, Guixi, Jiangxi, China). The mousetraps were set in different habitats (farmlands, bushes and woodlands, etc.) in the evening and checked the following morning. The captured animal hosts were separately put into premarked cloth bags and then transferred to the laboratory where the animal hosts were anesthetized. Each anesthetized animal host was placed in a large white square tray to collect

Table 1. The 91 investigation sites and the captured sites where the striped field mice (Apodemus agrarius) were captured in southwest China (2001-2019)

\begin{tabular}{|c|c|c|c|c|c|c|c|c|}
\hline No. & Abbr. & Investigation sites & No. & Abbr. & Investigation sites & No. & Abbr. & Investigation sites \\
\hline 1 & AY & Anyue* & 32 & JY & Jiangyang (Luzhou city) & 63 & SM & Simao \\
\hline 2 & $\mathrm{BC}$ & Binchuan & 33 & $K R$ & Karuo (Changdu city) & 64 & SN & Sinan $^{*}$ \\
\hline 3 & BY & Bayi (Linzhi city) & 34 & LC & Longchuan & 65 & $\mathrm{SZ}$ & Shizhu* \\
\hline 4 & CS & Changshou* & 35 & LH & Lianghe & 66 & SZh & Shizhong (Leshan city) * \\
\hline 5 & $\mathrm{CY}$ & Cangyuan & 36 & $\mathrm{LHo}$ & Luhuo* & 67 & $\mathrm{TN}$ & Tongnan* \\
\hline 6 & DC & Daocheng & 37 & $\mathrm{LL}$ & Luliang & 68 & $\mathrm{TZ}$ & Tongzhi* $^{\star}$ \\
\hline 7 & DJ & Dianjiang $^{*}$ & 38 & LLi & Longli & 69 & WS & Wenshan \\
\hline 8 & $\mathrm{DL}$ & Dali & 39 & LP & Lanping & 70 & WuS & Wusheng* \\
\hline 9 & $\mathrm{DQ}$ & Deqin & 40 & LS & Lushui & 71 & $W X$ & Weixi \\
\hline 10 & DY & Daying* & 41 & $L X$ & Luxian* & 72 & WY & Weiyuan* \\
\hline 11 & DYu & Duyun & 42 & LZ & Lezhi* $^{*}$ & 73 & WZ & Wanzhou \\
\hline 12 & FC & Fucheng (Mianyang city) ${ }^{\star}$ & 43 & MEK & Maerkang & 74 & $\mathrm{XC}$ & Xiangcheng \\
\hline 13 & $F G$ & Fugong & 44 & $M G$ & Maguan & 75 & XGLL & Xianggelila* \\
\hline 14 & $\mathrm{FL}$ & Fuling & 45 & $\mathrm{MH}$ & Menghai & 76 & $\mathrm{XH}$ & Xuanhan \\
\hline 15 & $\mathrm{FY}$ & Fuyuan & 46 & MK & Mangkang & 77 & $X X$ & Xixiu (Anshun city) \\
\hline 16 & GD & Guiding* & 47 & $\mathrm{ML}$ & Mengla & 78 & $X Z$ & Xuzhou (Yibin city) \\
\hline 17 & GL & Guanling & 48 & MLi & Muli & 79 & YaJ & Yajiang \\
\hline 18 & GM & Gengma & 49 & MN & Mianning & 80 & YD & Yongde \\
\hline 19 & GS & Gongshan & 50 & MY & Miyi & 81 & YJ & Yuanjiang \\
\hline 20 & $\mathrm{GZ}$ & Ganzi $^{*}$ & 51 & $\mathrm{MZ}$ & Mengzi & 82 & $Y L$ & Yulong* \\
\hline 21 & HK & Hekou & 52 & $\mathrm{NE}$ & Ninger & 83 & YoY & Youyang \\
\hline 22 & HS & Huishui* & 53 & $\mathrm{PA}$ & Puan & 84 & YuY & Yunyang \\
\hline 23 & $H X$ & Huaxi (Guiyang city)* & 54 & PC & Pingchang & 85 & YY & Yanyuan \\
\hline 24 & HY & Hongya* & 55 & PS & Plngshan & 86 & ZA & Zhengan* \\
\hline 25 & $\mathrm{JC}$ & Jianchuan & 56 & $\mathrm{QB}$ & Qiubei & 87 & ZF & Zhenfeng \\
\hline 26 & $\mathrm{JH}$ & Jinghong & 57 & QJ & Qiaojia & 88 & ZJ & Zhijin \\
\hline 27 & JJ & Jiangjin* & 58 & QW & Qianwei & 89 & ZS & Zhongshanzx (Liupanshui city) \\
\hline 28 & JK & Jiangkou & 59 & RJ & Rongjiang & 90 & $Z X$ & Zhongxian \\
\hline 29 & $J P$ & Jinping & 60 & $\mathrm{RL}$ & Ruili & 91 & $\mathrm{ZZ}$ & Zizhong* \\
\hline 30 & JS & Jinsha* $^{*}$ & 61 & RS & Renshou* & & & \\
\hline 31 & JT & Jintang* ${ }^{*}$ & 62 & SJ & Suijiang & & & \\
\hline
\end{tabular}

${ }^{*}$ Captured sites where the striped field mice (Apodemus agrarius) were captured. 
chigger mites separately. The edges of the large white square tray were smeared with insect repellent to prevent the mites from escaping. With the help of a magnifier, curette and lancet, the larvae of chigger mites (chiggers) were collected from the body surface of each host, mainly from the host's auricle and external auditory canal where most chiggers attached. All the collected chiggers were preserved in $70 \%$ ethanol vials and they were then made into glass-slide specimens by using Hoyer's medium and finally identified into species under a microscope $[1,14]$. The capture and use of animals for research were officially approved by the local wildlife affairs authority and the Animal Ethics Committee of Dali University. The approval number of animal ethics was DLDXLL2020-1104. Representative animal hosts and chigger mites are deposited in the specimen repository of the Institute of Pathogens and Vectors of Dali University.

\section{Infestation statistics}

The constituent ratio $\left(C_{r}\right)$, prevalence $\left(P_{M}\right)$, mean abun- dance $\left(M_{A}\right)$ and mean intensity $\left(M_{I}\right)$ were used to calculate the infestation of the mouse A. agrarius (host) with chigger mites. For the test of statistical significance, Chi-square test $\left(\chi^{2}\right)$ was used for $P_{M}$, and Mann-Whitney test and Kruskal-Wallis test were used for $M_{A}$ and $M_{I}$. The formulae of $C_{r}, P_{M}, M_{A}$, and $M_{I}$ are as follows $[5,15]$.

$$
C_{r}=\frac{N_{i}}{N} \times 100 \% \quad P_{M}=\frac{H_{M}}{H} \times 100 \% \quad M_{A}=\frac{M}{H} ; \quad M_{l}=\frac{M}{H_{M}} ;
$$

In the above formulae, $N_{i}=$ the individuals of chigger mite species $i$ on the host (A. agrarius); $N=$ the total individuals of all the species of chigger mites, $H=$ the total individuals of hosts; $H_{M}=$ the individuals of infested hosts with chigger mites, and $M=$ the individuals of chigger mites infested.

\section{Measurement of spatial distribution patterns}

Cassie index $\left(C_{A}\right)$ was used to measure the spatial distribution pattern of the dominant mite species among the different individuals of the host $A$. agrarius [16-18].

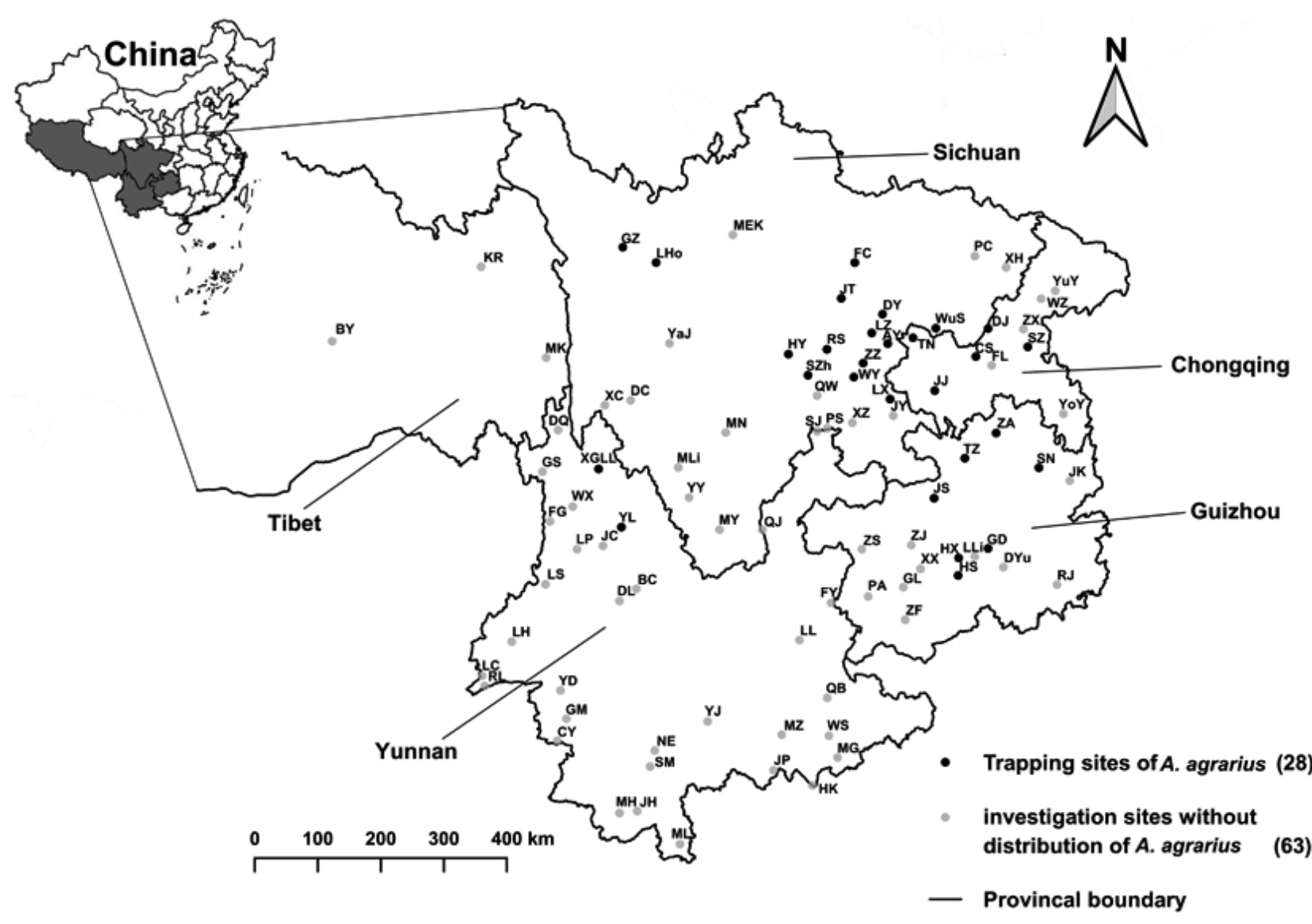

Fig. 1. The 91 investigation sites and the captured sites where the striped field mice (Apodemus agrarius) were captured in southwest China (2001-2019). 


$$
C_{A}=\frac{\sigma^{2}-m}{m^{2}}
$$

In the above formula, $\mathrm{m}$ and $\sigma^{2}$ represent the mean and variance of chigger mites on the host $A$. agrarius. When $C_{A}>0$, the spatial distribution was determined as the aggregated distribution, while $C_{A}=0$ is a random distribution, and $C_{A}<0$ is an even distribution [16-18].

\section{Measurement of interspecific association}

Based on the establishment of a contingency table (see Table 4 in "Results"), the association coefficient (V) was used to measure the interspecific association between any 2 species of chigger mites (chigger species) on the mouse host A. agrarius. Chi-square test was used for testing the statistical significance of $V[19,20]$.

$$
V=\frac{a d-b c}{\sqrt{(a+b)(c+d)(a+c)(b+d)}}
$$

In the above formula, $V=$ the association coefficient between chigger species $\mathrm{X}$ and $\mathrm{Y} ; a=$ the host individuals on which chigger species X and Y simultaneously occur; $b=$ the host individuals on which chigger species Y occurs, but chigger species $\mathrm{X}$ does not occur; $c=$ the host individuals on which chigger species X occurs, but chigger species $\mathrm{Y}$ does not occur; and $d=$ the host individuals on which both chigger species $\mathrm{X}$ and $\mathrm{Y}$ do not occur. When $V>0$ and $P<0.05$, the interspecific relationship between chigger species $\mathrm{X}$ and $\mathrm{Y}$ is determined as the positive association, and when $V<0$ and $P<0.05$, the negative association. And $P$ is the significance probability in Chi-square test $\left(\chi^{2}\right)$.

\section{Calculation of species similarity}

Sorensen index ( $\left.C_{S S}\right)$ was used to measure the species similarity of chigger species on male and female hosts, A. agrarius $[21,22]$.

$$
C_{S S}=\frac{2 C}{S_{m}+S_{f}}
$$

In the above formula, $S_{m}=$ the number of chigger species on male hosts, $S_{f}=$ the number of chigger species on female hosts, and $C=$ the common species of chigger mites on male and female hosts.

\section{RESULTS}

\section{Investigation sites}

The field investigations were carried out in 91 investigation sites (counties) of 5 provincial regions (Yunnan, Guizhou, Chongqing, Sichuan and Tibet) in southwest China between 2001 and 2019 (Table 1; Fig. 1). The striped field mice, A. agrarius, were captured in 28 sites of 91 investigated ones (Table 1; Fig. 1).

\section{Collection and identification of chigger mites}

A total of 715 striped field mice (A. agrarius) were captured from 28 sites of 91 investigated ones in southwest China. The result showed that $A$. agrarius mice were not distributed in all the region of southwest China and they were mainly from Sichuan, Chongqing and Guizhou (Fig. 1). From the body surface of 715 A. agrarius mice, only 255 individuals of chigger mites (chiggers) were collected, and they were identified as 14 species, 6 genera in 3 subfamilies under 2 families. The collect-

Table 2. Identified chigger mites from striped field mice (Apodemus agrarius) in southwest China between 2001 and 2019

\begin{tabular}{ll}
\hline Taxonomic taxa of chigger mites & \multicolumn{1}{c}{$\begin{array}{c}\text { Species and individuals of chigger mites } \\
\text { (The single figures in parentheses reflect the number of individuals for each mite species) }\end{array}$} \\
\hline $\begin{array}{l}\text { 1. Family Trombiculidae } \\
\text { 1.1 Subfamily Trombiculinae }\end{array}$ & L. hanseni (21) L. cricethrionis (12) L. yui (3) L. rupestre (38) L. sialkotense (118) \\
$\begin{array}{l}\text { 1.1.1 Genus Leptotrombidium } \\
\text { 1.1.2 Genus Neotrombicula }\end{array}$ & N. aeretes (5) \\
$\begin{array}{l}\text { 1.1.3 Genus Schoengastiella } \\
\text { 1.2 Subfamily Gahrliepiinae }\end{array}$ & S. novoconfusiana (33) \\
$\begin{array}{l}\text { 1.2.1 Genus Walchia } \\
\text { Genus Gahrliepia }\end{array}$ & W. koi (2) W. kritochaeta (3) \\
$\begin{array}{l}\text { 2. Family Leeuwenhoekiidae } \\
\text { 2.1 Subfamily Leeuwenhoekiinae }\end{array}$ & G. eurypunctata (2) W. nanfangis (4) G. yangchenensis (6) G. orientalis (1) \\
2.1.1 Genus Chatia & C. maoyi (2) \\
Total & 250 individuals, 14 species, 6 genera, 3 subfamilies, 2 families \\
\hline
\end{tabular}

Five individuals of chigger mites were not identified into species (unidentified chiggers) and they were not included in the above table. 
ed 255 chigger mites were much less than 715 examined hosts, A. agrarius mice (Table 2).

\section{Infestation and spatial distribution of dominant species of chigger mites}

Of 715 hosts (A. agrarius mice) examined, only 24 of them were infested with chigger mites with overall prevalence $P_{M}=3.36 \%$, overall mean abundance $M_{A}=0.36$ mites/host and overall mean intensity $M_{I}=10.63$ mites/host. Of 14 species of chigger mites identified from the host A. agrarius, 3 of them were dominant chigger species and they were Leptotrombidium sialkotense (also called $L$. jishoum in China) with the constituent ratio $C_{r}=46.27 \%$, L. rupestre with $C_{r}=14.90 \%$ and Schoengastiella novoconfuciana with $C_{r}=12.94 \%$. The total constituent ratio of 3 dominant species of chigger mites reached $74.12 \%$ (189/255). Leptotrombidium sialkotense was the first dominant chigger species with highest constituent ratio and infestation indices, $C_{r}=46.27 \%, P_{M}=0.98 \%, M_{A}=0.17$ mites $/$ host and $M_{I}=16.86$ mites/host (Table 3).

The Cassie indices $\left(C_{A}\right)$ of 3 dominant species of chigger mites were much higher than the border value "0" for determining the aggregated distribution and all the dominant species conformed to the aggregated distribution pattern among different individuals of their mouse host, A. agrarius (Table 3).

\section{Analysis on interspecific association between dominant species of chigger mites}

The analysis on interspecific association between any 2 dominant species of chigger mites showed that the association coefficients $(V)$ were $V=-0.008$ between $L$. sialkotense ( $L$. jishoum) and $L$. rupestre and $V=-0.003$ between $L$. sialkotense and $S$. novoconfuciana, which were very close to 0 . The 2 association coefficients $(V)$, however, were of no statistical significance with $P>0.05$ (Table 4).

\section{Species similarity of chigger mites on male and female hosts}

The result showed that the Sorensen index of chigger mites on male and female hosts (A. agrarius) was 0.25 ( $C_{S s}=0.25$, which means the species similarity of chigger mites on male and female hosts was low.

\section{DISCUSSIONS}

In comparison with the species richness and diversity of chigger mites on some other species of rodents in southwest China, the species diversity of chigger mites on striped field mice (A. agrarius) was quite low with only 14 chigger species collected from 715 mice. A previous investigation showed that there were abundant species of chigger mites on the body sur-

Table 3. The constituent ratios, infestation indices and dispersion coefficient of three dominant species of chigger mites on striped field mice (Apodemus agrarius) in southwest China (2001-2019)

\begin{tabular}{|c|c|c|c|c|c|c|}
\hline \multirow[t]{2}{*}{ Dominant species of chigger mites } & \multicolumn{2}{|c|}{$\begin{array}{l}\text { Constituent ratios of } \\
\text { chigger mites }\end{array}$} & \multicolumn{3}{|c|}{$\begin{array}{l}\text { Infestations of Apodemus agrarius mice } \\
\text { with chigger mites }\end{array}$} & \multirow{2}{*}{$\begin{array}{c}\text { cassie index } \\
C_{A}\end{array}$} \\
\hline & Individuals & $C_{r}(\%)$ & $P_{M}(\%)$ & $M_{A}$ & $M_{i}$ & \\
\hline L. sialkotense (L. jishoum) & 118 & 46.3 & 1.0 & 0.17 & 16.86 & 288.51 \\
\hline L. rupestre & 38 & 14.9 & 0.7 & 0.05 & 7.6 & 185.46 \\
\hline S. novoconfuciana & 33 & 12.9 & 0.1 & 0.05 & 33 & 693.33 \\
\hline Total 14 species of chigger species & 255 & 100 & 3.4 & 0.36 & 10.63 & 87.31 \\
\hline
\end{tabular}

$C_{r}=$ constituent ratio, $P_{M}=$ prevalence, $M_{A}=$ mean abundance, $M_{l}=$ mean intensity and $C_{A}=$ Cassie index.

Table 4. Analysis on interspecific association between any two dominant species of chigger mites on striped field mice (Apodemus agrarius) in southwest China (2001-2019)

\begin{tabular}{|c|c|c|c|c|c|c|}
\hline & \multicolumn{3}{|c|}{ L. rupestre } & \multicolumn{3}{|c|}{ S. novoconfuciana } \\
\hline & + & - & total & + & - & total \\
\hline \multicolumn{7}{|l|}{ L. sialkotense } \\
\hline+ & $0(a)$ & $7(b)$ & $7(a+b)$ & $0(a)$ & $7(b)$ & $7(a+b)$ \\
\hline - & $5(c)$ & $703(d)$ & $708(c+d)$ & $1(c)$ & 707 (d) & $708(c+d)$ \\
\hline Total & $5(a+c)$ & $710(b+d)$ & $715(n)$ & $1(a+c)$ & $714(b+d)$ & $715(n)$ \\
\hline Association coefficient & & $V=-0.008$ & & & $V=-0.003$ & \\
\hline Chi-square & & $x^{2}=0.336$ & & & $x^{2}=4.525$ & \\
\hline Significance & & $>0.05$ & & & $>0.05$ & \\
\hline
\end{tabular}


face of some wild rodents. A total of 51 chigger species were once collected from 916 Yunnan red-backed voles (Eothenomys miletus), a typical wild rodent species, in a localized area of southwest China [23]. Another previous study revealed that 31 chigger species were collected from 451 house rats (Rattus flavipectus) in 6 counties of Yunnan Province, southwest China [24]. In the present study, the species diversity (species richness) of chigger mites on A. agrarius mice was very low in comparison with that on E. miletus voles and $R$. flavipectus rats. Besides very low species diversity of chigger mites, the infestations of $A$. agrarius mice with chiggers in the present study were also very low with overall $P_{M}=3.4 \%$ and overall $M_{A}=0.36$ mites $/$ mouse (Table 3), which were much lower than those on E. miletus voles (overall $P_{M}=61.1 \%$ and overall $M_{A}=32.80 \mathrm{mites} /$ mouse) and R. flavipectus rats (overall $P_{M}=18.2 \%$ and overall $M_{A}=4.69$ mites/mouse) in southwest China $[23,24]$ The results may imply that the striped field mouse (A. agrarius) in southwest China may not be susceptible to the infestation of chigger mites in comparison with some other species of rodents in the same geographical region. Some previous studies showed that the species diversity and infestations of chigger mites were associated with a series of factors including different species of rodent hosts, different geographical regions, altitudes and habitats $[20,25]$. Different species of rodents with different biological characteristics are very different in susceptibility of infesting with chigger mites and some other ectoparasites $[15,26]$. The results of the present study further suggest that the infestations of rodents with chigger mites are very different on different species of rodent hosts. Some previous studies showed that the species diversity and infestations of chigger mites on some rodents in outdoor and wild habitats were much higher than those in indoor habitats, which reflects the influence of different habitats on the infestation of the mites [24,26]. The outdoor and wild habitats (farmlands, bush areas and woodlands, etc.) are often more suitable for chigger mites to survive, develop and reproduce and some rodents living in the outdoor and wild habitats would have much more opportunities to infest with chigger mites than those in the indoor habitats $[15,24,26]$. The striped field mouse (A. agrarius) is a typical wild species of rodent and it is mainly distributed in various crop fields, farmlands and nearby wild habitats in the distributed regions $[8,9]$. As a typical wild species of rodent, A. agrarius should have more opportunities to infest with chigger mites $[9,23]$, but the opposite fact is that the species diversity and infestations of chigger mites on A. agrarius mice are very low in southwest
China. The species composition and infestation of chigger mites on A. agrarius mouse in southwest China were very different from those on the same rodent species (A. agrarius) in some other geographical regions, for example in north and northeast China and Republic of Korea $[12,13,27]$. The results of the present study imply that the chigger infestations may greatly fluctuate on a certain species of rodent in different geographical regions. The specific population of A. agrarius mouse in southwest China may be different from some other populations of A. agrarius in some other geographical regions, and $A$. agrarius mouse in southwest China seems to have a very low susceptibility to chigger infestations. The low susceptibility of A. agrarius mouse in southwest China to chigger mite infestations may be due to some biological characteristics of A. agrarius population in southwest China. To illustrate the different susceptibility of different geographical populations of A. agrarius to chigger mite infestations, more researches are needed.

Previously some local investigations once reported the species composition and infestation of chigger mites on the striped field mouse (A. agrarius) in some parts of north and northeast China and Republic of Korea [12,13,27]. A previous investigation from Shandong Province of northern China reported 5 chigger species collected from the body surface of 167 A. agrarius mice, and the 5 chigger species were Leptotrombidium scutellare, L. palpalis, L. linhuaikonense, L. intermedia and Walchia pacifica [12]. The investigation from the border area of northeast China reported 8 species of chigger mites found on 1964 A. agrarius mice, and the 8 chigger species were Leptotrombidium liaoji, L. orientale, L. subintermedium, L. pavlovskyi Neotrombicula gardellai, N. japonica, N. tamizai and N. zhmajevae [13]. A total of 865 chigger mites were once collected from 171 A. agrarius mice, which were caught at Pochun-gun of Gyeonggi Province and Chinhae-city of Kyongnam Province in Republic of Korea, and they were identified as 7 chigger species, Leptotrombidium pallidum, L. palpale, L. orientalis, L. zetum, Neotrombicula tamiyai, N. japonica and Euschongastia koreaensis [28]. The previous reports revealed the fact that the species diversity of chigger mites on A. agrarius mouse was quite low with only 5 to 8 species identified, which was even much lower than that in the present study (14 chigger species). The species composition of chigger mites from the previous reports was very different from that in the present study (Table 2). Besides the different species composition, the overall prevalence of chigger infestation on A. agrarius in southwest China (overall $P_{M}=3.4 \%$ ) was also very different from those in Shandong Province of 
northern China (overall $P_{M}=81.4 \%$ ), the border area of northeast China (overall $P_{M}=18.9 \%$ ) and the east coast of Republic of Korea (overall $P_{M}=93.2 \%$ ) $[12,13,27]$. The results of the present study revealed the fact that the species diversity and the infestation of chigger mites on the same species of rodent (e.g., A. agrarius) would greatly fluctuate in different geographical regions, which may be associated with different latitudes, altitudes and climates in different regions. Some previous studies indicated that the species diversity, species composition and infestation of chigger mites and some other ectoparasites would be influence by a series of factors including different geographical regions with different latitudes and altitudes, and different climates with different temperature, humidity and rainfall, etc. $[20,25,29]$. The results of the present indicate that the species composition and infestation of chigger mites on A. agrarius vary with different geographical regions, and different geographical populations of A. agrarius mouse may have different susceptibilities to chigger mite infestations.

Of 14 species of chigger mites found on A. agrarius in the present study, 3 of them were the dominant species, namely $L$. sialkotense (L. jishoum), L. rupestre and S. novoconfuciana, and $L$. sialkotense was the first dominant chigger species with highest constituent ration $\left(C_{r}\right)$ and infestation indices $\left(P_{M}, M_{A}\right.$, and $M_{I}$ ) (Table 3). Of the 3 dominant chigger species, L. sialkotense is one of 6 main vectors of scrub typhus in China, and L. rupestre is a potential vector of scrub typhus $[19,30,31]$. The striped field mouse (A. agrarius) is an important reservoir host of $O$. tsutsugamushi, the causative agent of scrub typhus. Apodemus agrarius is often found in the cultivated areas such as crop fields and some other kinds of farmlands and it is closely associated with human activities $[8,9]$. The occurrence of $L$. sialkotense on the body surface of $A$. agrarius with a high constituent ratio $\left(C_{r}=46.3 \%\right)$ would probably increase the possibility of the mites' biting humans and would further increase the possibility of transmitting scrub typhus from the mouse to human beings through the mites' biting activity.

Based on Cassie index $\left(C_{A}\right)$, the spatial distribution of 3 dominant species of chigger mites was determined as aggregated distribution among different individuals of their mouse host, A. agrarius (Table 3). The aggregated distribution of chigger mites on A. agrarius is highly consistent with the results in some previous studies on chigger mites and some other ectoparasites [15]. The aggregated distribution is a very common distribution pattern of ectoparasites including chigger mites. It indicates that the distribution of chigger mites on rodent hosts is very uneven. Some host individuals harbor the mites in groups with clumps of mites on them and some other host individuals have few or no mites on their body surface. The aggregated distribution may be beneficial to the survival, spread, mating, reproduction and defense of the parasites [26], and it may also facilitate the transmission of some zoonotic diseases by vector mites from rodents to humans.

The analysis of the interspecific relationship between any 2 different species is an important issue in animal ecology. The association coefficient $(V)$ used in the present study is a simple way to measure the interspecific relationship between any 2 species $[20,26,32]$. When $V>0$ and $P<0.05$, the interspecific relationship between any 2 species (species $\mathrm{X}$ and $\mathrm{Y}$ ) is determined as positive association, which indicates that the 2 species have a tendency of co-existence. When $V<0$ and $P<0.05$, the interspecific relationship is determined as negative association, which indicates that the 2 species have a tendency of mutual repulsion. When $V=0$ or very close to 0 , the interspecific relationship is determined as no association, which indicates that the 2 species exist or distribute independently $[20,26,32]$. The association coefficients $(V)$ between any 2 of 3 dominant chigger species (L. sialkotense, L. rupestre and S. novoconfuciana) were very close to 0 (Table 4 ), which seems to be of no association between any 2 chigger species. However, the 2 association coefficients $(V)$ were of no statistical significance $(P>0.05)$ and a further investigation with more host samples may be needed.

The values of Sorensen index $\left(C_{S S}\right)$ used in the present study range from 0 to 1 , which is a simple way to measure the species similarity of 2 communities. Nowadays, Sorensen index $\left(C_{S S}\right)$ has been widely used in the ecological study of communities [21,26]. The chigger mites on male and female hosts of rodents and other small mammals can be regarded as 2 community units and therefore Sorensen index can be used in measuring the species similarity of chigger mites on male and female hosts. The result of the present study showed that the Sorensen index of chigger mites on male and female hosts ( $A$. agrarius) was quite low ( $C_{S S}=0.25$, not beyond 0.5 ), which means the species compositions of chigger mites on the male and female hosts (A. agrarius) are very different with low similarity. The results suggest that different genders of the hosts harbor different chigger species, which reflects the sex-bias of different genders of the hosts in harboring different species of chigger mites. The result further suggests that gender differences of rodent hosts (e.g., A. agrarius) may have a great influence on 
their infestations with different species of chigger mites and some other ectoparasites $[15,21]$.

\section{ACKNOWLEDGMENTS}

We would express our sincere thanks to the following people who made lots of contributions in the field investigations and laboratory work: Yun-Ji Zou, Qiao-Hua Wang, Wen-Yu Song, Yong Zhang, Cong-Hua Gao, Nan Zhao, Jian-Chang He, Guo-Li Li, Yan-Liu Li, Xue-Song He, De-Cai Ouyang, ShuangLin Wang, some colleagues and college students. The project was supported by the National Natural Science Foundation of China (No. 81960380 and 82160400) to Xian-Guo Guo, and the Innovation Team of Vector Biology, Dali University (No. ZKLX2019104). We also thank to the financial supports of the funds.

\section{CONFLICT OF INTEREST}

There are no conflicts of interest related to this study.

\section{REFERENCES}

1. Li JC, Wang DQ, Chen XB. Trombiculid mites of China (studies on vector and pathogen of tsutsugamushi disease). Guangzhou, China. Guangdong Science and Technology Publishing House. 1997, pp 1-570.

2. Chakraborty S, Sarma N. Scrub typhus: An emerging threat. Indian J Dermatol 2017; 62: 478-485. https://doi.org/10.4103/ijd. IJD_388_17

3. Peng PY, Guo XG, Jin DC, Dong WG, Qian TJ, Qin F, Yang ZH. Species abundance distribution and ecological niches of chigger mites on small mammals in Yunnan province, southwest China. Biologia 2017; 72: 1031-1040. https://doi.org/10.1515/biolog2017-0119

4. Latif A, Liu BY, Chen Z, Sun Y, Shi YL, Zong J, Li JJ, Ren CP, Zhang XC, Liu XN, Yu XJ, Liu Y. Orientia tsutsugamushi infection in rodents in Anhui province of China. Infect Genet Evol 2017; 56: 14-18. https://doi.org/10.1016/j.meegid.2017.10.014

5. Peng PY, Guo XG, Jin DC, Dong WG, Qian TJ, Qin F, Yang ZH, Fan R. Landscapes with different biodiversity influence distribution of small mammals and their ectoparasitic chigger mites: a comparative study from southwest China. PLoS One 2018; 13: e0189987. https://doi.org/10.1371/journal.pone.0189987

6. Xiang R, Guo XG. Advances in research on Leptotrombidium scutellare. J Pathogen Biol 2020; 15: 1473-1479 (in Chinese). https:// doi.org/10.13350/j.cjpb.201221

7. Wu YC, Qian Q, Magalhaes RJ, Han ZH, Haque U, Weppelmann TA, Hu WB, Liu YX, Sun YS, Zhang WY, Li SL. Rapid increase in scrub typhus incidence in mainland China, 2006-2014. Am J Trop Med Hyg 2016; 94: 532-536. https://doi.org/10.4269/ajtmh.150663

8. Wlison DE, Lacher TE, Mittermeier RA. Handbook of Mammals of the World. Vol.7. Rodents II. Barcelona, Spain. Lynx Edicions. 2017, pp 781.

9. Huang WJ, Chen YX, Wen YX. Rodents of China. Shanghai, China. Fudan University Press. 1995, pp 1-308 (in Chinese).

10. Zhang F, Gong Z, Zhang J, Liu Z. Prevalence of Borrelia burgdorferi sensu lato in rodents from Gansu, northwestern China. BMC Microbiol 2010; 10: 157. https://doi.org/10.1186/1471-2180-10157

11. Ni H, Yang F, Li Y, Liu W, Jiao S, Li Z, Yi B, Chen Y, Hou X, Hu F, Ding Y, Bian G, Du Y, Xu G, Cao G. Apodemus agrarius is a potential natural host of severe fever with thrombocytopenia syndrome (SFTS)—causing novel bunyavirus. J Clin Virol 2015; 71: 82-88. http://dx.doi.org/10.1016/j.jcv.2015.08.006

12. Huang XD, Cheng P, Zhao YQ, Li WJ, Zhao JX, Liu HM, Kou JX, Gong MQ. Chigger mite (Acari: Trombiculidae) survey of rodents in Shandong province, northern China. Korean J Parasitol 2017; 55: 555. https://doi.org/10.3347/kjp.2017.55.5.555

13. Liu GP, Ren QM, Wang F. Investigation of Apodemus agrarius and its ectoparasites in frontiers of Russia and northeast China. Chin J Hyg Insect Equip 2006; 12: 465-467 (in Chinese). https://xueshu.baidu.com/usercenter/paper/show?paperid=b71b788b13a2 d4fd588201d0c6029e0a\&site=xueshu_se

14. Stekolnikov AA. Leptotrombidum (Acari: Trombiculidae) of the world. Zootaxa 2013; 3728: 1-173. http://doi.org/10.11646/zootaxa.3728.1.1

15. Ding F, Guo XG, Song WY, Fan R, Zhao CF, Mao KY, Zhang ZW, Peng PY, Lin H, Dong WG, Qian TJ, Yang ZH, Zou YJ. Infestation and distribution of chigger mites on brown rat (Rattus norvegicus) in Yunnan province, southwest China. Trop Biomed 2021; 38: 111-121. https://doi.org/10.47665/tb.38.1.020

16. Kuno E. Sampling and analysis of insect populations. Annu Rev Entomol 1991; 36: 285-304. https://doi.org/10.1146/annurev. en.36.010191.001441

17. Zhang XM, Liu XJ, Yang ZJ. Studies on the spatial distribution pattern of Lygus lucortum Meyer-Dur's over winter eggs in jujube trees. Chinese J Eco Agric 2006; 14: 157-159 (in Chinese). https://xueshu.baidu.com/usercenter/paper/show?paperid=f52985f6cf559b 128cec00aaf8a0e435\&site=xueshu_se\&hitarticle $=1$

18. Cassie RM. Frequency distribution modes in the ecology of plankton and other organism. J Anim Ecol 1962; 31: 65-92. https://doi.org/10.2307/2333

19. Lv Y, Guo XG, Jin DC, Song WY, Fan R, Zhao CF, Zhang ZW, Mao KY, Zou YJ, Yang ZH. Relative abundance of a vector of scrub typhus, Leptotrombidium sialkotense, in Southern Yunnan Province, China. Korean J Parasitol 2020; 58: 153-159. https:// doi.org/10.3347/ kjp.2020.58.2.153

20. Yin PW, Guo XG, Jin DC, Fan R, Zhao CF, Zhang ZW, Huang XB, Mao KY. Distribution and host selection of tropical rat mite, Ornithonyssus bacoti, in Yunnan province of southwest China. Animals 
2021; 11: 110. https://doi.org/10.3390/ani11010110

21. Peng PY, Guo XG, Song WY, Hou P, Zou YJ, Fan R, He XS. Analysis of ectoparasites (chigger mites, gamasid mites, fleas and sucking lice) of the Yunnan red-backed vole (Eothenomys miletus) sampled throughout its range in Southwest China. Med Vet Entomol 2015; 29: 403-415. https://doi.org/10.1111/mve.12134

22. Morales G, Pino LA. Parasitología Cuantitativa. Caracas, Venezuela. Fundación Fondo Editorial, Acta Científica Venezolana. 1987, pp 132 (in Spanish).

23. Guo XG, Speakman JR, Dong WG, Men XY, Qian TJ, Wu D, Qin F, Song WY. Ectoparasitic insects and mites on Yunnan red-backed voles (Eothenomys miletus) from a localized area in southwest China. Parasitol Res 2013; 112: 3543-3549. https://doi.org/10.1007/ s00436-013-3537-6

24. Guo XG, Qian TJ, Meng XY, Dong WG, Shi WX \& Wu D. Preliminary analysis of chigger communities associated with house rats (Rattus flavipectus) from six counties in Yunnan, China. Syst Appl Acarol 2006; 11: 13-21. https://doi.org/10.11158/saa.11.1.2

25. Peng PY, Guo XG, Ren TG, Song WY, Dong WG, Fan R. Species diversity of ectoparasitic chigger mites (Acari: Prostigmata) on small mammals in Yunnan Province, China. Parasitol Res 2016a; 115: 3605-3618. https://doi.org/10.1007/s00436-016-5127-x

26. Liu Z, Guo XG, Fan R, Zhao CF, Mao KY, Huang ZW, Zhao Y. Ecological analysis of gamasid mites on the body surface of Norway rats (Rattus norvegicus) in Yunnan Province, Southwest China. Biologia 2020; 75: 1325-1336. https://doi.org/10.2478/s11756-01900383-Z

27. Park GM, Shin HS. Geographical distribution and seasonal indi- ces of chigger mites on small mammals collected on the east coast of the Republic of Korea. J Parasitol 2016; 102: 193-198. https://doi.org/10.1645/15-760

28. Ree HI, Baek LJ, Lee HW, Paik YH. Trombiculid mites (Acarina: Trombiculidae) from Apodemus agrarius coreae caught at pochungun, Gyeonggi province and chinhae-city, Kyongnam province. Korean J Parasitol 1989; 27: 141-144. http://doi.org/10.3347/ kjp.1989.27.2.141

29. Huang H. Ecological research of chigger mites on three species of wild rodents (Apodemus chevrieri, etc.) in Yunnan province. M Sc Thesis. Dali University; 2014 (in Chinese). https://xueshu.baidu.com/usercenter/paper/show?paperid=9f96417dbda64e793a 23fd8b323b101c\&site=xueshu_se\&hitarticle $=1$

30. Su JJ, Wang Y, Zhou J, Bin Y, Yang ZQ. Advances in research of tsutsugamushi disease epidemiology in China in recent years. Chin J Hyg Insect Equip 2012; 18: 160-163 (in Chinese). https:// doi.org/10.19821/j.1671-2781.2012.02.026

31. Wu GH, Jiang ZK, Wang L, Ding LY, Mao CQ, Ma BY. Accordance and identification of vector chigger mites of tsutsugamushi disease in China. Chin J Hyg Insect Equip 2013; 19: 286-292. (in Chinese). https://xueshu.baidu.com/usercenter/paper/show?pa perid=3774775c273dd22ff9c343763972597e\&site=xueshu_ se\&hitarticle $=1$

32. Peng PY, Guo XG, Song WY, Hou P, Zou YJ, Fan R. Ectoparasitic chigger mites on large oriental vole (Eothenomys miletus) across Southwest, China. Parasitol Res 2016; 115: 623-632. https://doi. org/10.1007/s00436-015-4780-9 
